\title{
ESTUDO DA VIABILIDADE DO USO DE GPS PARA O MONITORAMENTO DE VEICULOS DE PASSEIO NA REGIÃO DE ORLÂNDIA-SP
}

GONÇALVES, Gabriel Ananias ${ }^{1}$ TAVARAYAMA, Rodrigo ${ }^{2}$

RESUMO: O objetivo do presente trabalho foi analisar a importância da viabilidade da utilização do Sistema de Rastreamento e Monitoramento de veículos de passeio e de navegadores GPS para traçar rotas, indicar trajetos e condições da via em tempo real para o auxílio do condutor, para isso foi realizada uma pesquisa de campo com dez corretores de seguradoras na região da Cidade de Orlândia, interior do Estado de São Paulo. Com o resultado da pesquisa, nota-se que é satisfatória a utilização do sistema, tanto para a segurança, no caso de bloqueio e localização de veículos furtados e roubados, quanto para a comodidade dos clientes, no monitoramento de seus veículos.

Palavras-chaves: GPS. Sistema de Posicionamento Global. Monitoramento. Rastreamento via satélite.

\section{VIABILITY STUDY OF THE USE OF GPS FOR THE MONITORING OF VEHICLES TO RIDE IN THE REGION OF ORLÂNDIA-SP}

SUMMARY: The objective of this study was to analyze the importance of the viability of using the System Tracking and Monitoring passenger vehicle and GPS navigators to plot routes, state routes and track conditions in real time to aid the driver, for this was done a field study with ten insurance brokers in the region of Orlando, the State of São Paulo. With the search result, note that it is satisfactory to use the system, both for security in case of locking and locating stolen vehicles and stolen, and for the convenience of our customers in monitoring their vehicles.

Keywords: GPS. Global Positioning System. Monitoring. Satellite tracking.

\section{INTRODUÇÃO}

Em um mundo cada vez mais globalizado e marcado pelas novas tecnologias, a tecnologia GPS - Global Positioning System (Sistema de Posicionamento Global) vem sendo cada dia mais acessível para a população, com os preços cada vez mais baixos, esta tecnologia está em alta evolução em vendas. Em viagens um dispositivo GPS pode ser um grande aliado e companheiro, o aparelho permite a uma pessoa se localizar em qualquer ponto do território terrestre, instantaneamente e com baixa margem de erro. Esta tecnologia é uma revolução que

\footnotetext{
${ }^{1}$ Bacharel em Sistemas de Informação FE/FAFRAM.

2 Orientador. Mestre em Educação. Especialista em Educação Especial e Atendimento Educacional Especializado. Bacharelado e Licenciado em Ciências Sociais. Prof. FE/FFCL/FAFRAM.
} 
já começou a transformar o cotidiano da humanidade, aliás, tecnologias da comunicação e informação representam uma profunda mudança na organização, educação da sociedade e da economia.

Atualmente existe uma grande preocupação com a segurança dos veículos. Companhias de seguro cada vez mais incentivam seus clientes a possuírem algum sistema de localização que auxilie na recuperação de veículos roubados. O sistema vem sendo muito eficaz, segundo Marcelo Sebastião, gerente de produto automóvel da Porto Seguro, "as seguradoras oferecem até $30 \%$ de desconto no valor do premio da apólice para os clientes mediante a instalação de rastreador no veículo". Para alguns veículos o rastreador é requisito obrigatório para a contratação do seguro. Em casos de roubo, o índice de recuperação do veículo com a ajuda do rastreador GPS chega a 98\% (ARIMA, 2008).

No presente trabalho buscou-se uma alternativa a esses sistemas baseado em GPS Veiculares, que são equipamentos de baixo custo que cada vez mais são utilizados por motoristas para se localizar em viagens, passeios, entre outros. O interesse pelo tema de pesquisa foi pelo qual o sistema GPS está sendo cada dia mais acessível para a população em geral e muitas pessoas conhecem as funcionalidades de um GPS, sistema de uso obrigatório em aviões e aeroportos, e normalmente já vinham sendo utilizados em navios e na agricultura, mas que a população não tinha acesso a tal recurso.

O objetivo desse trabalho foi realizar um estudo da viabilidade do uso de GPS para o monitoramento de veículos de passeio e por meio de uma pesquisa de campo com proprietários de corretoras de seguros para veículos, os dados foram analisados a fim de elucidar a importância, as vantagens e desvantagens da instalação de um rastreador veicular que utiliza o sinal GPS para o seu funcionamento. O avanço das tecnologias eletroeletrônicas e de sistemas de posicionamento global tem proporcionado a produção de aparelhos de custo acessível à sociedade, fazendo com que esta altere a maneira de enxergar sua inserção no contexto geoespacial, vislumbrando novas aplicações da tecnologia a cada vez mais em outros tipos de segmentos.

\section{REVISÃO DE LITERATURA}

A revisão de literatura é uma parte importante em todo trabalho científico, pois é o momento onde se procura levantar dados relativos ao tema proposto a fim de conhecer como tal temática vem sendo discutida e sua importância no atual contexto social. Assim dividimos a revisão de literatura em 3 tópicos para melhor entendimento do tema.

Nucleus, v.8, n.2, out.2011 
No primeiro tópico foi abordado o tema da evolução da navegação para que no segundo tópico pudéssemos então entrar na temática do trabalho que é o GPS e por último no terceiro tópico foi analisado o mercado de rastreamento no Brasil.

\subsection{A EVOLUÇÃ̃ DA NAVEGAÇÃO}

A noção de posição/espaço é tão antiga quanto à presença do ser humano na Terra. Com o passar dos anos, caminhando passo a passo, foi ocorrendo o desenvolvimento da ciência chamada Navegação. Para ter o conhecimento de posições, foi criado um instrumento para saber a posição terrestre e enxergar o magnetismo do pólo norte independente de qualquer condição meteorológica. A Bússola possivelmente de origem chinesa, iria chegar a Europa por volta do ano 1000. A partir do século XIII tornou-se extremamente popular entre os navegadores, uma agulha imantada, flutuando numa tigela com água, aponta sempre para o norte da Terra. A bússola fornecia a direção da nau (denominação genérica dada a navios de grande porte até o século XV), mas não era capaz de dar a posição da nau. Para se chegar a determinação de um ponto na superfície terrestre era necessário que definisse um sistema de coordenadas e um ponto de origem. Com o aprofundamento do conhecimento da geometria terrestre, foram criados na Grécia os conceitos de latitude e de longitude (PAZ; CUGNASCA, 2010).

Com o aprofundamento do conhecimento da geometria terrestre, foram criados na Grécia os conceitos de latitude e de longitude. Conceito de Latitude: de localização, norte ou sul, em relação à linha do equador. Conceito de Longitude: de localização, leste ou oeste, em relação a um Meridiano de referência, sendo este adotado hoje pelo Observatório de Greenwich, na Inglaterra (MACHADO, 2010).

A Bússola magnética e o sextante, instrumentos estes que na época, possibilitaram o completo conhecimento de todas as terras do mundo. A bússola: mostrava o caminho relativo a seguir, por sempre mostrar o norte verdadeiro, o Sextante: determinava a latitude, pois mostrava a medida exata dos ângulos acima do horizonte do sol, da lua e das estrelas, pela posição destes em um almanaque especifico que se determinava a latitude, por um almanaque especifico sabia-se que o exatamente ao meio-dia o sol estava acima de Greenwich, e o horário de medida do sextante, as 14h00min, sabia-se que a posição era de duas horas a oeste de Greenwich (MACHADO, 2010).

Estes instrumentos foram utilizados por muitos anos até o inicio do século XX, até então, vários sistemas de navegação foram desenvolvidos, sistemas que precisavam de 
receptores especiais a bordo para que pudessem ser usados. Estes sistemas foram aperfeiçoados e intensamente empregados para a navegação de aeronaves e navios na Segunda Guerra Mundial. Sistemas estes que apresentavam problemas, pois eram Sistemas de grande alcance, mas de baixa precisão e Sistemas de grande precisão, mas de baixo alcance. A utilização destes sistemas obrigava que as aeronaves e os navios a fazerem o uso de diversos sistemas a bordo.

E assim utilizando os mesmo princípios dos sistemas de navegação do passado e do presente com bases em solo, passando a ter o uso de sistemas de satélites, possibilitando pela primeira vez o uso de um sistema com alta precisão e máximo alcance em um único sistema (MACHADO, 2010).

\subsection{GPS}

A tecnologia atual permite que qualquer pessoa possa se localizar no planeta com uma grande precisão. O sofisticado sistema que tornou realidade isso possível é chamado GPS Global Positioning System (Sistema de Posicionamento Global), e foi concebido pela Forças Armadas e o Departamento de Defesa dos Estados Unidos da América (Departament of Defense) no início da década de 1960, combinaram recursos tecnológicos para desenvolver um sistema de navegação de alta precisão baseado em satélites, sob o nome de Projeto NAVSTAR.

O sistema GPS entrou em operação em 1991 e em 1993 a constelação dos satélites utilizados pelo sistema foi concluída. Segundo Machado (2010), o sistema foi declarado totalmente operacional apenas em 1995. Seu desenvolvimento custou 10 bilhões de dólares. Consiste de 24 satélites específicos do sistema, com 6 planos de órbita com $55^{\circ}$ de inclinação, sendo quatro satélites em cada plano, separados em arcos de $60^{\circ}$, de 2 a 5 satélites também são mantidos em órbita como reservas para uso imediato, a órbita de um satélite é percorrida em aproximadamente, 12 horas, duas voltas ao redor da terra por dia.

O Sistema GPS é composto por três segmentos: Segmento Espacial, Segmento de Controle e Segmento de Usuários.

\subsubsection{SEGMENTO ESPACIAL}

A função do segmento espacial é transmitir os sinais de navegação GPS, de forma contínua e permanente. O Segmento espacial é composto pela constelação dos 24 satélites artificiais da Terra que emitem sinais eletromagnéticos. Satélites também referidos como Veículos Espaciais (SV), que se compõem com as seguintes características básicas, conforme 
ensina autor Washington Machado.

Peso: aproximadamente $1.500 \mathrm{Kg}$;

Energia: Solar;

Dimensões: cerca de 3 x 13 metros;

Relógios Atômicos: 4 (quatro) com precisão de 10-12;

Transmissores: rádio frequiências portadoras na banda de UHF e de baixa potencia, sendo as básicas designados de L1 (1.575,42 MHz) e L2 (1.227,60MHz);

Vida útil Média: 12 anos.

Os 24 satélites estão distribuídos em 6 órbitas distintas, o que faz com que qualquer ponto da superfície terrestre tenha pelo menos 4 satélites acima da linha do horizonte, a uma altitude aproximada de $20.000 \mathrm{~km}$ da superfície, a posição de cada satélite é conhecida a cada instante, pois as transmissões de radiofreqüência são unidirecionais. Desta forma, utilizandose os receptores GPS, é possível localizar qualquer ponto por meio de suas coordenadas em três dimensões (Latitude, Longitude e Altitude).

Um satélite é alimentado de energia solar, os painéis solares retráteis quando estendidos conferem ao satélite um comprimento de aproximadamente 13 metros, e 3 metros de largura, sua massa, em órbita, é de aproximadamente $1.500 \mathrm{Kg}$. Em cada satélite há 4 Relógios Atômicos altamente precisos, calibrados na freqüência de $10,23 \mathrm{MHz}$, ou seja, com estabilidade de 1 em 1.000.000.000.000 segundos, o que significa que levará cerca de 32.000 anos para adiantar ou atrasar 1 segundo; Transmissores: rádio frequiências portadoras na banda de UHF e de baixa potencia, sendo as básicas designados de L1 (1.575,42 MHz) e L2 $(1.227,60 \mathrm{MHz})$. Os sinais (L1 e L2) trafegam em linha direta, o que significa que, embora ultrapassem nuvens, vidros e plásticos, são obstruídos por objetos mais sólidos, tais como prédios e montanhas (MACHADO, 2010).

Embora os relógios atômicos sejam muito precisos, sofrem pequenas derivas, traduzindo em erros de distâncias ao respectivo satélite, estima-se em cerca de três metros a incerteza padrão das distâncias por influencias da deriva dos relógios dos satélites.

O relógio dos aparelhos receptores, sendo mais impreciso, fornece uma incerteza maior sobre as distâncias. No entanto, a deriva do relógio do receptor é resolvida pela sua determinação em conjunto com as coordenadas da antena do referido receptor. Dai que, como mencionado, sejam necessárias quatro distâncias para os respectivos satélites para obter, com um mínimo de rigor, uma solução para o posicionamento (PRATES, Gonçalo, 2004). 
Os sinais emitidos pelos satélites sofrem alteração da velocidade de propagação da trajetória dos sinais em direção á antenas receptoras. Em geral, separam-se as influências da parte ionizada, associada à ionosfera, e da parte neutra da atmosfera, associada à troposfera. A ionosfera aumenta a velocidade de propagação das frequências portadoras para além da velocidade da luz, e assim podendo alcançar 10 metros de distancia de incerteza nos sinais. A troposfera, além de diminuir a velocidade de propagação, refrata ${ }^{3}$ a onda curvando a trajetória, ambas contribuindo para aumento das distâncias, e assim contribui com 2 metros de incerteza, aumentando à medida que o satélite se aproxima da linha do horizonte.

Superfícies refletoras nas proximidades das antenas receptoras também podem influenciar nos sinais emitidos pelos satélites, resultando na degradação do sinal, dificultando a observação do tempo de propagação e da diferença de fase necessária para a determinação da distância. Esta influencia do sinal refletido denominado de multitrajeto, impõe uma incerteza de aproximadamente 1 metro e meio na localização (PRATES, GONÇALO, 2004).

\subsubsection{Sinais de uso Geral}

Rádio frequências L1 (1.575,42 MHz) e L2 (1.227,60MHz) moduladas com o código C/A (Coarse/Acquisition) conhecidas também como Código Civil. Estes códigos podem ser acessados livremente por qualquer receptor GPS. Os sinais são denominados de Standard Positioning Service (SPS) "serviço de posicionamento padrão", sinais que são livremente comercializados em todo o mundo. (MACHADO, 2010).

A precisão alcançada pelos usuários do SPS até a data de primeiro de maio de 2000 era de $100 \mathrm{~m}$ na horizontal, $145 \mathrm{~m}$ na vertical e 340 nano-segundos nas medidas de tempo, com nível de confiança de 95\%. A partir do dia dois de Maio de 2000 o sistema teve uma melhoria de 10 vezes em seu nível de precisão (MONICO, 2000).

\subsubsection{Sinais de uso Restrito}

Rádio frequências L1 e L2 moduladas com o código $\mathrm{P}(\mathrm{Y})$, sendo $\mathrm{P}$ (código de precisão), (Y) um código de proteção contra interferências e transmissões falsas. P é referente e destinado a definições de posição com maior precisão. São de uso privativo do Governo dos Estados Unidos da América. Ambos os códigos são acessados por receptores especiais e não liberados para comercialização. Os sinais são denominados de Precise Positioning Service

${ }^{3}$ Refrata: Desviar-se de sua primitiva direção.

Nucleus, v.8, n.2, out.2011 
(PPS) "serviço de posicionamento de precisão". A precisão no PPS é em torno de 1 a $5 \mathrm{~m}$, com nível de confiança de 95\% (MONICO, 2000).

O código $\mathrm{P}$ serve para identificar cada satélite e para medir o tempo de percurso da onda desde o satélite até ao receptor.

\begin{abstract}
$\mathrm{Na}$ realidade o sistema $\mathrm{DoD}^{4}$ pode oferecer uma melhor acurácia ${ }^{5}$ e precisão, porem ao que tudo indica não há interesse em oferecer um serviço mais preciso, pois isso poderia pôr em risco a segurança dos EUA. Para garantir a segurança do sistema os militares nortes americanos criaram uma forma de deteriorar a acurácia e precisão adotando, para isto, dois processos limitantes do posicionamento dos sinais emitidos pelos satélites do sistema. Para a frequência de uso militar foi criado o AntiSpoofing (AS) e para uso civil o Selective Availability (SA). O AS é um processo de criptografia do código $\mathrm{P}$, um dos códigos utilizados no GPS para realizar medidas de distância, visando protegê-lo de imitações por usuários não autorizados... A partir de 2 de maio de 2000, essa técnica de deterioração da acurácia para o uso civil foi abolida, melhorando algo em torno de dez vezes o seu nível de acurácia. Os receptores capazes de trabalhar com os dois códigos de correção são chamados de dupla frequência com as portadoras L1 e L2. Atualmente a precisão dos GPS geodésicos que trabalham com as duas portadoras é da ordem de $1 \mathrm{~mm}$ na horizontal e de $5 \mathrm{~mm}$ na vertical e tal precisão é extremamente importante para estudos geodésicos e espaciais em micro e macro escala (BERNARDI; LANDIM, 2010, p4).
\end{abstract}

Atualmente a precisão dos GPS geodésicos que trabalham com as duas portadoras é da ordem de $1 \mathrm{~mm}$ na horizontal e de $5 \mathrm{~mm}$ na vertical e tal precisão é extremamente importante para estudos geodésicos e espaciais em micro e macro escala (BERNARDI; LANDIM,2010).

\title{
1.2.2 SEGMENTO DE CONTROLE
}

Este segmento é composto pelas estações terrestres que mantêm os satélites em funcionamento e também são responsáveis pela manutenção do segmento espacial.

A rede mundial de estações tem como função, monitorar os sinais transmitidos pelos satélites, processá-los, efetuar eventuais correções em suas órbitas e em seus relógios, quando necessário, emitir sinais de comando de posicionamento dos satélites e de correção dos dados do Segmento Espacial (Constelação GPS). O segmento de controle é constituído por cinco estações de monitoramento, localizadas em Ascencion, Colorado, Diego Garcia, Kwajalein e Hawai. E uma estação de controle em Colorado Springs. A rede de estações é formada pelos seguintes elementos: 1 Estação Máster de Controle (MCS), 5 Estações de Monitoramento (MS) e Quatro Antenas Terrenas (GA) (MACHADO, 2010).

\footnotetext{
${ }_{5}^{4}$ DoD (Departament of Defense) Departamento de Defesa dos Estados Unidos da América.

5 Acurácia é o grau de concordância entre o valor estimado para uma grandeza e o considerado "verdadeiro".
} 
A constelação de satélites GPS é gerenciada e controlada a partir da Estação Máster de Controle. Os dados coletados pelas Estações de Monitoramento são processados na Estação Máster de Controle e o seu pessoal técnico pode, com base nesses dados, transmitir comandos aos satélites para corrigir eventuais problemas técnicos. (MACHADO, 2010, p12).

As estações são distribuídas pela superfície terrestre e localizadas em: a de Colorado Springs, no oeste dos Estados Unidos; a do Havaí no Oceano Pacífico, Estados Unidos; a de Kwajalein, nas ilhas norte americanas das Carolinas, também no Oceano Pacífico; a da ilha de Ascensão, possessão Britânica do Atlântico Sul; e a da ilha de Diego Garcia, também de possessão britânica, no Oceano Índico. A estação de Colorado Springs abriga o centro de operações do sistema, a Estação de Controle. No cabo Carnaveral, no estado norte-americano da Flórida, fica a estação de lançamento dos satélites (PAZ; CUGNASCA, 2010).

\begin{abstract}
As mensagens de correção emitidas pela Estação Máster de Controle aos satélites são transmitidas por meio de Antenas Terrenas (GS) localizadas junto a três das Estações de Monitoramento. No caso de ser detectado um problema mais sério com um dos satélites, a Estação Máster de Controle transmite uma mensagem de "não confiável", que faz com que os receptores GPS o não façam uso de suas informações para o cálculo de posição e tempo. ... pode levar até 45 minutos para que um satélite com defeito seja declarado "não confiável". Essa demora é inaceitável para o uso do GPS na navegação aérea, sendo necessário o emprego de infraestrutura, terrestre e/ou espacial, complementar ao GPS ('sistemas de aumentação') e de receptores GPS de aeronaves dotados de dispositivo de monitoramento autônomo da integridade do GPS (RAIM), para assegurar um efetivo e instantâneo controle da integridade do sistema (MACHADO, 2010).
\end{abstract}

As Estações de Monitoramento (Ascension, Colorado, Diego Garcia, Kwajalein, Hawai) rastreiam continuamente e monitoram os satélites. Os dados coletados são automaticamente transmitidos para a Estação de Controle, onde os dados são processados e se determina as eventuais necessidades de correções dos traçados das órbitas e dos dados de navegação (MACHADO, 2010).

\title{
1.2.3 SEGMENTO DE USUÁRIOS
}

Segmento composto pelos receptores, que captam os sinais enviados pelos satélites e, com eles, calcula a sua posição.

Normalmente, os receptores de GPS e softwares disponíveis no mercado podem variar de $\mathrm{R} \$ 290,00$ um modelo simples, denominados de baixa precisão, até $\mathrm{R} \$ 90.000,00$ para um conjunto geodésico de alta precisão mais utilizado na agricultura para medições de área de talhões ou perímetro de propriedades agrícolas. Para algumas finalidades, os modelos simples

Nucleus, v.8, n.2, out.2011 
ainda se mostram superiores em vários aspectos, como na vantagem de localização instantânea, facilidade de manuseio, portabilidade e baixo custo de aquisição (SISTEMA, 2010).

\begin{abstract}
Um receptor rastreia um satélite pela recepção de seu sinal. Sinais de apenas quatro satélites são necessários para obtenção de uma posição fixa tridimensional, mas é desejável um receptor que rastreie mais de quatro satélites simultaneamente. Com o usuário se desloca, o sinal de algum satélite pode ser bloqueado repentinamente por algum obstáculo, restando satélites suficientes para orientá-lo. A maioria dos receptores rastreia de 8 a 12 satélites ao mesmo tempo. Um receptor não é melhor que outro por rastrear mais satélites. Rastrear satélites significa conhecer suas posições. Não significa que o sinal daquele satélite está sendo usado no cálculo da posição. Muitos receptores calculam a posição com quatro satélites e usam os sinais do quinto para verificar se o cálculo está correto (GORGULHO, 2009, s.p.).
\end{abstract}

O funcionamento do GPS é baseado através do método da trilateração, o receptor pode obter suas coordenadas geográficas (latitude, longitude e sua altitude), e pode, ainda, determinar o instante atual, com altíssima precisão.

A trilateração utiliza os satélites como pontos de referência a geometria, cumprindo um papel fundamental no cálculo da posição do receptor na Terra. Em qualquer ponto do planeta é possível obter uma precisão de até 1 metro. Para entender como funciona a trilateração, será utilizado o conceito da trilateração em duas dimensões (2D), sendo que os cálculos para GPS utiliza três dimensões $(3 \mathrm{G})$, por questões de simplificação para que o método seja entendido (Gasparoto; Paim; Menta, 2010).

\title{
1.2.4 ASSISTED-GPS (A-GPS)
}

O dispositivo GPS tem obstáculos que dificultam a recepção do sinal de satélites como árvores, edifícios, céu nublado e montanhas. O sinal do satélite pode sofrer bastante interferência e acabar alterando o resultado da localização. Por este motivo o aparelho receptor não funciona bem no subsolo ou em túneis, nem dentro de alguns modelos de carros, que tem placas metálicas no teto ou no pára-brisa e blindagem. Por este motivo a indústria associa o GPS a outras tecnologias, é a tecnologia denominada Assisted-GPS(A-GPS). Assisted significa que o GPS é ajudado por outro sistema. Enquanto o GPS comum se localiza usando somente o sinal dos satélites, o A-GPS utiliza os mesmos satélites em conjunto com uma rede de telefonia móvel, é um sistema mais rápido e mais preciso que o GPS convencional, obtendo coordenadas com mais rapidez e precisão. Esta tecnologia também fornece dados de divergência dos mapas locais para GPS (GUIMARÃES, 2010). 


\title{
1.2.5 GPS DIFERENCIAL (DGPS)
}

O sistema DGPS consiste em correção de erros, esta técnica requer que os usuários obtenham os receptores específicos que necessitam obter a coordenada em tempo real (com maior precisão que no modo absoluto), os sinais recebidos pelos receptores são emitidos por satélites de comunicação geoestacionários, ou seja, por satélites com a suas coordenadas conhecidas que recebem os sinais GPS do mesmo conjunto de satélites, determinando o efeito do conjunto dos erros, que são corrigidos por estações de referência, e assim corrigindo as coordenadas de antenas nas proximidades, em cada instante de medição (PRATES, G. 2004).

Em países como Estados Unidos, Rússia, Japão e grande parte da Europa utilizam esta técnica de correção de sinais no setor de aviação, a precisão na técnica DGPS pode chegar a uma margem de erro de 1 a 3 metros (GONÇALVES, R. et al, 2010).

\subsubsection{DISPOSITIVOS GPS}

O mercado atual é composto por uma quantidade ilimitada de receptores GPS, cada aparelho é apropriado a propósitos a que se destinam nas mais diversas funções, como: receptor de navegação, receptor geodésico, receptor para SIG (Sistema de Informações Geográficas), receptor para medir a área ou perímetro de propriedades agrícolas, receptor de aquisição de tempo etc. O receptor é uma parte integrante do Sistema GPS e onde a posição e tempo são calculados. É em nível dos receptores que todo o sistema GPS se torna utilizável.

\begin{abstract}
A categoria de usuários pode ser dividida em civil e militar. Os militares fazem uso dos receptores GPS para estimar suas posições e deslocamentos quando realizam manobras de combate e de treinamento. Durante a operação Tempestade no Deserto, na Guerra do Golfo, em 1991, vários receptores GPS foram utilizados para auxílio no deslocamento nas regiões desérticas, onde não há feições factíveis de serem localizadas num mapa. Esse fato foi muito noticiado pela imprensa. Muitas outras atividades militares fazem uso do posicionamento com receptores GPS, como, por exemplo, na navegação de mísseis... Atualmente, há uma grande quantidade de receptores no mercado civil, para as mais diversas aplicações, limitadas apenas pela imaginação dos usuários, o que demonstra que o GPS realmente atingiu sua maturidade (MONICO, 2000, p.10 - 11).
\end{abstract}

Os receptores GPS recebem, descodificam e processam os sinais emitidos pelos satélites a partir dos quais se faz o cálculo da posição, velocidade e tempo do utilizador. Para calcular a distância entre o satélite e o receptor, o receptor mede o tempo decorrido entre o envio e a recepção do sinal enviado pelo satélite, é o tempo em que o sinal percorre entre o envio pelo satélite e a recepção pelo receptor, o receptor multiplica o tempo pela velocidade de deslocamento do sinal, assim o receptor obtém a sua distância até o satélite. Os relógios internos dos receptores não são tão precisos como os dos satélites o que pode causar pequenos erros de medição do tempo (PAZ; CUGNASCA, 2010). 
O receptor tem como função básica a captação dos sinais emitidos pelos satélites que estiverem visíveis, sem nenhuma obstrução entre o satélite e o receptor, e descodificando e processando estes sinais, o receptor calcula a sua posição através do método da trilateração, obtendo suas coordenadas geográficas (latitude, longitude e sua altitude). Os receptores normalmente são multi-canais, ou seja, um receptor pode acompanhar um satélite por canal, um receptor com 12 canais poderá acompanhar os sinais de até 12 satélites ao mesmo tempo (MACHADO, 2010).

Um aparelho receptor tem como seus componentes: uma antena com pré-amplificador, seção de radio freqüência para identificação e processamento do sinal, um microprocessador para o processamento dos dados, oscilador, que amplifica e reproduz sinais repetitivos, uma tela de interface para o usuário, memória para armazenar os dados, provisão de energia e painel de exibição e comandos (MONICO, 2000).

\subsubsection{RASTREADOR}

O Equipamento que compõe o sistema de rastreamento e monitoramento de veículos é um equipamento de alto valor se não for levado em consideração o custo/benefício do sistema, para adquirir o equipamento o cliente terá que investir aproximadamente $\mathrm{R} \$ 800,00$ pelo equipamento e mais a mensalidade com valor aproximado de $\mathrm{R} \$ 89,00$, dependendo da opção do cliente, pois tem vários tipos de regalias que ele poderá obter, como exemplo: o monitoramento do veículo em tempo real, via internet, o cliente faz o login no site da empresa em que oferece o serviço de rastreamento e monitoramento e ele poderá localizar o seu veículo em tempo real o obter informações de velocidade do veículo, pontos de parada, velocidades mínima e máxima atingida, etc. (BRANCO,2010).

As peças que compõem o Kit para o sistema de rastreamento e monitoramento de veículos são: antena GPS, Antena GPRS(Global Packet Radio Service), é a comunicação rápida e eficiente entre veículo a central através da rede de dados que permite o envio e a recepção de informações através de uma rede de telefonia móvel. Não é relacionado ao GPS. Os sensores para travamento e destravamento das portas, abertura e fechamento dos vidros, o sistema que bloqueia e desbloqueia o motor do veículo, uma bateria de backup, um módulo que obtêm as coordenadas, velocidade atual, informações da quantidade de satélites captados e a qualidade do sinal, velocidade excedida pré-programada, alarmes de ignição, ao uso da chave do veículo, botão de pânico, o botão pode ser acionado pelo usuário em caso de seqüestro ou furto (CARDOSO, 2007). 


\subsection{O MERCADO DE RASTREAMENTO}

O ano de 2010 é um ano com muitas novidades para as empresas do setor de monitoramento e rastreamento de veículos, com a resolução 245, do CONTRAN (Conselho Nacional de Trânsito), esta resolução obriga o uso de dispositivos de segurança denominados antifurto em automóveis, e com isso há um crescimento visível no setor de rastreamento e monitoramento de veículos.

RESOLUÇAO N. 245 DE 27 DE JULHO DE 2007

Dispõe sobre a instalação de equipamento obrigatório, denominado antifurto, nos veículos novos saídos de fábrica, nacionais e estrangeiros.

Considerando a necessidade de dotar os órgãos executivos de trânsito de instrumentos modernos e inter-operáveis para planejamento, fiscalização e gestão do trânsito e da frota de veículos;

Considerando o que consta do Processo no 80001.003014/2007-99,

Art. $1^{\circ}$ - Todos os veículos novos, saídos de fábrica, produzidos no País ou importados a partir de 24 (vinte e quatro) meses da data da publicação desta Resolução somente poderão ser comercializados quando equipados com dispositivo antifurto.

$\S 1^{\circ}$ - O equipamento antifurto deverá ser dotado de sistema que possibilite o bloqueio e rastreamento do veículo.

Art. $4^{\circ}$ - Caberá ao proprietário do veículo decidir sobre a habilitação do equipamento junto aos prestadores de serviço de rastreamento e localização, definindo o tipo e a abrangência do mesmo (CONTRAN, 2007).

No Brasil, o mercado de rastreamento e monitoramento de veículos enfrentou muitas dificuldades no passado, para o seu desenvolvimento, pelo fato da grande dificuldade de adaptação dos equipamentos nos veículos, pois interferiam no funcionamento normal do veículo, provocando interferência na arquitetura elétrica do funcionamento dos veículos, causando assim, transtornos para os proprietários dos mesmos. Nos dias atuais isto já não é um problema para as empresas e nem para os proprietários dos veículos, pois este cenário teve um amadurecimento significativo de uma crescente evolução, a grande parte dos equipamentos respeita as condições mínimas do funcionamento, assim não interferindo no funcionamento dos veículos. O setor de rastreamento e monitoramento, agora sofre de mãode-obra qualificada para instalação e manutenção dos equipamentos, elemento crucial na eficiência do funcionamento do dispositivo e em caso de furto, na recuperação do veículo (FRANCO. 2009).

O mercado de rastreamento e monitoramento teve um aumento muito acelerado, devido ao crescimento no uso de Smartphones, iPhone e pela ampliação do ambiente wireless. Estima-se que no ano de 2009 o setor de Rastreamento e monitoramento teve um faturamento maior que 2 bilhões de dólares, só na América Latina houve um investimento de 12 milhões 
de dólares no setor, segundo a companhia mundial de pesquisas em tecnologia Gartner. No evento NAVTEQ GLOBAL LBS Challenge 2010, que a NAVTEQ promoveu, o Brasil se destacou levando os prêmios de primeiro e terceiro lugares, pelo potencial das empresas em criar soluções voltadas para o usuário (BRANCO; PRESTES, 2010).

Com um crescimento visível, segundo Elias Kabeche, gerente geral da TomTom na América Latina, o Brasil tem atualmente 33 milhões de veículos, e menos de $2 \%$ destes veículos utilizam o sistema de localização via GPS, portanto, o setor tem muito espaço para crescer. Já o gerente geral da Movix, Carlos Roberto Borges, afirma que em 2009 foram mais de 36 mil equipamentos vendidos no primeiro quadrimestre, em 2010 no mesmo período foram vendidos 149 mil equipamentos (BRANCO. 2010).

Em entrevista a Revista InfoGPS, 19 executivos representantes das empresas de tecnologia que fazem parte do mercado de Rastreamento, Monitoramento e Gerenciamento de Risco, dividem opiniões a respeito de como pretendem manter/expandir suas metas para atender a demanda das tendências do mercado. Entre as opiniões estão: Investir em treinamento de consultores, sistema de gestão de qualidade, aprimorarem as soluções em hardware e software, investir em produtos com interações com o usuário, focar no desenvolvimento de monitoramento remoto com mecanismos de prevenção de acidentes para melhorar a qualidade de direção do veículo, implementar os novos lançamentos da linha de rastreadores e sistemas de monitoramento como equipamento sem fio e bateria independente, rastreador para motos que podem ser instalados em lugares imperceptíveis. Algumas empresas investiram mais de 3,5 milhões de reais em hardwares e softwares, outras que chegaram a crescer $100 \%$ em apenas 6 meses. E algumas se encontram em processo de preparação para a certificação ISO 9001:2008 (BRANCO; PRESTES. 2010).

\section{METODOLOGIA}

Os recursos metodológicos utilizados neste trabalho foram à pesquisa bibliográfica com revisão de literatura e pesquisa de campo. A pesquisa bibliográfica foi desenvolvida com base em material constituído de livros, revistas e artigos científicos e informações divulgadas pela mídia. Enquanto a pesquisa de campo foi realizada por meio de entrevistas agendadas ou enviadas as seguradoras na região de Orlândia. Os dados foram tabulados e analisados qualitativamente o que permitiu entender melhor a natureza do problema (RICHARDSON, 1999).

Por motivos de um acordo no ato da pesquisa, os nomes das seguradoras não foram 
divulgados, por tanto foram nomeadas por números conforme pode ser observado na tabela 1.

\begin{tabular}{l|c|c|c|c|c}
\hline $\begin{array}{c}\text { NÚMERO DE } \\
\text { SEGURADORAS }\end{array}$ & $\begin{array}{c}\text { T. R. } \\
\text { Corr. }\end{array}$ & $\begin{array}{c}\text { Qnt. } \\
\text { Seguradoras }\end{array}$ & Qnt Seg. Anual & V. Desconto \% & $\begin{array}{c}\text { Clientes c/ } \\
\text { Rastreador }\end{array}$ \\
\hline Seguradora 1 & 12 & 5 & 300 & 10 a 15 & $\approx 20$ \\
\hline Seguradora 2 & 22 & 7 & 1000 & 0 a 10 & $\approx 6$ \\
\hline Seguradora 3 & 3 & 1 & 360 & 10 a 30 & - \\
\hline Seguradora 4 & 20 & 13 & 850 & 0 a 10 & $\approx 50$ \\
\hline Seguradora 5 & 18 & 3 & 60 & 5 a 15 & 0 \\
\hline Seguradora 6 & 22 & 7 & 1.000 & 0 & 0 \\
\hline Seguradora 7 & 9 & 6 & - & 15 a 25 & $\approx 18$ \\
\hline Seguradora 8 & 15 & 13 & $\approx 1.000$ & 0 & $\approx 100$ \\
\hline Seguradora 9 & 13 & 1 & - & 0 a 5 & $\approx 3$ \\
\hline Seguradora 10 & 20 & 13 & 850 & 0 a 30 & $\approx 150$ \\
\hline
\end{tabular}

Tabela 1. Dados Capitulados do Questionário.

Fonte: Dados da pesquisa do autor.

Legenda: T.R.Corr.: Tempo no ramo anos (corretor). Qnt. Seguradoras.: Quantas Seguradoras trabalha. Qnt Seg. Anual: Quantidade de seguros ao ano. V. Desconto: Valor do desconto ao cliente com o rastreador. Clientes c/ Rastreador: Quantidade de clientes que usam o rastreador veicular.

Foram enviados 22 questionários, sendo 9 entrevistas com a presença do autor, 1 realizada por meio de telefone, 9 questionários foram enviados por email, sendo nenhum deles foram devolvidos, 1 corretor não respondeu o questionário justificando ter pouco tempo no ramo e não ter as informações para realizar a pesquisa, 2 corretores se recusaram a responder o questionário por motivos de sigilo bancário.

\section{ANÁLISE E DISCUSSÃO DE DADOS}

Para realizar esta pesquisa foram aplicados questionários a 10 corretores de seguros que trabalham com diversas seguradoras de veículos, que atuam no mercado de 3 a 22 anos, na região da cidade de Orlândia, interior do estado de São Paulo.

Para realizar as análises dos dados foram abordadas as seguintes questões:

- $\quad$ A opção do cliente ao optar pelo seguro;

- $\quad$ A quantidade de seguradoras que oferecem o rastreador veicular;

- $\quad$ Os clientes que já optaram pelo sistema de rastreamento e monitoramento;

- $\quad \mathrm{O}$ desconto ao cliente que possuir um rastreador no veículo. 


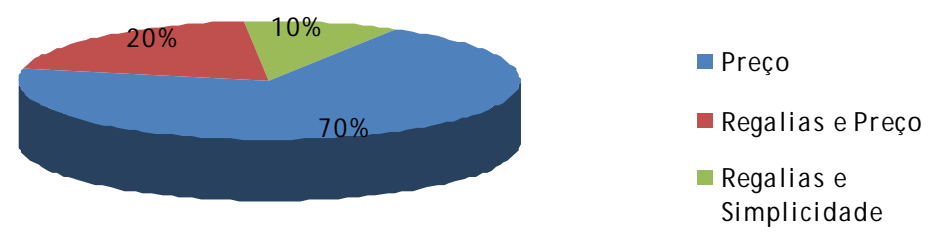

Gráfico 1. Opção do cliente ao optar pelo seguro.

Fonte: Pesquisa do Autor.

Pode-se observar no gráfico 1, sobre a opção do cliente ao adquirir o seguro, que dentre as três opções: preço, regalias e simplicidade, é relevante o fator econômico (preço). É a opção que o cliente leva em maior consideração ao optar pelo seguro, com base de dados na pesquisa realizado pelo autor. No ato da pesquisa, os corretores afirmaram que os clientes optam pelo preço, muitas vezes sem pensar nos benefícios que posteriormente deixam de ter, principalmente o valor da franquia, que quanto menor o valor da apólice, maior é o valor da franquia. Custo este que o cliente só terá quando houver um sinistro, e dependendo do valor (valor inferior ao da franquia), o cliente tem que arcar com os custos para algum concerto ou reparo no veículo.

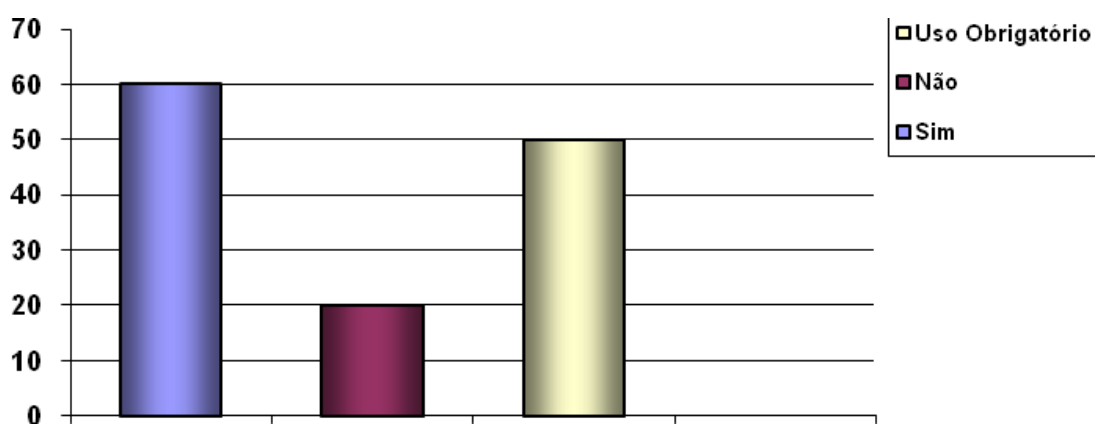

Gráfico 2. Seguradoras que oferecem Rastreador Veicular.

Fonte: Pesquisa do Autor.

O gráfico 2 mostra a porcentagem das seguradoras entrevistadas que oferecem o rastreador veicular, sendo que $60 \%$ delas oferecem o sistema de rastreamento e monitoramento veicular, $20 \%$ não oferecem o sistema, mas fazem o uso do mesmo caso o cliente queira. E 50\% das seguradoras, utilizam o sistema como de uso obrigatório se o veículo for de alto risco de furto e roubo. A seguradora instala o sistema de rastreamento e monitoramento em comodato, isto é, sem custo algum, só que o cliente só tem a posse e uso do sistema enquanto houver a apólice com a seguradora, caso contrário o equipamento será retirado do veículo. 


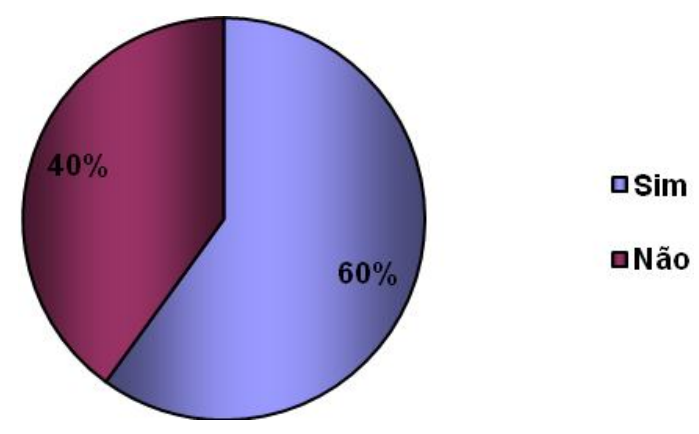

Gráfico 3. Clientes que optaram pelo sistema de rastreamento e monitoramento. Fonte: Pesquisa do autor.

Ao analisar a porcentagem de clientes das seguradoras que já optaram pelo sistema de rastreamento e monitoramento de veículos, foi possível observar que $60 \%$ dos clientes optaram pelo sistema de rastreamento e monitoramento. Haja vista, que a região possui um nível muito baixo de furtos e roubos de veículos. Segundo os corretores entrevistados, na região pesquisada ainda há pouca utilização do sistema de rastreamento de monitoramento se comparado a grandes cidades ou até mesmo a capital paulista, São Paulo na qual há o maior número de veículos que fazem o uso desta tecnologia. Pois lá o valor de uma apólice de seguro é alto se comparada com o interior do estado, mas também o índice de roubos e furtos é muito maior.

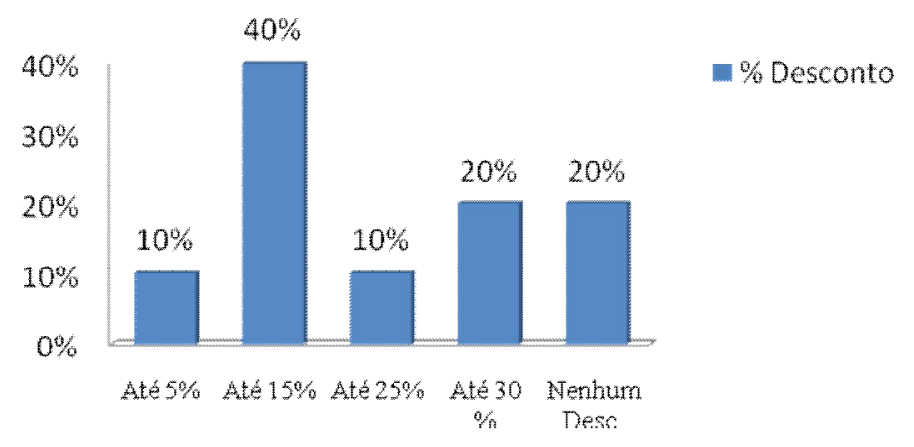

Gráfico 4. Porcentagem de Desconto

Fonte: Pesquisa do autor

O Gráfico 4 apresenta a porcentagem de desconto que as seguradoras oferecem aos clientes que optam pelo Sistema de Rastreamento e Monitoramento. Das seguradoras entrevistadas, $10 \%$ oferecem até $5 \%$ de desconto no valor do seguro; $40 \%$ delas até $15 \%$ de desconto; $10 \%$ até $25 \%$ de desconto; $20 \%$ até $30 \%$ de desconto e $20 \%$ não oferecem nenhum 
desconto. As seguradoras que oferecem até $30 \%$ de desconto no valor da apólice de seguro visam incentivar o cliente a utilizar o Sistema de Rastreamento e Monitoramento de veículos pela facilidade de localização e recuperação do veículo, diminuindo as indenizações a serem pagas aos clientes. Destes $20 \%$ das seguradoras que não oferecem nenhum desconto no valor do seguro, estão as que fazem o uso obrigatório do sistema, que a instalação é por conta da seguradora e o cliente não tem nenhum custo por isso, só não tem o desconto no valor da apólice ao adquirir ao seguro.

Portanto, considerando os dados nota-se que: o cliente leva em consideração a condição econômica ao optar pelo seguro de seu veículo, pouco mais da metade das seguradoras entrevistadas oferecem o sistema de rastreamento e monitoramento de veículos, e $60 \%$ dos clientes optam pelo sistema, mas possuem um número baixo de veículos com o equipamento instalado pelo fato de que na região que foi realizada a pesquisa o índice de furtos e roubos são muito baixos. Mas levando em consideração que um cliente pode ter um ou mais veículos.

\section{CONSIDERAÇÕES FINAIS}

A pesquisa teve como objetivo analisar a viabilidade do uso de GPS veicular para monitoramento de veículos de passeio na região de Orlândia, interior do estado de São Paulo, por meio de uma pesquisa de campo com corretores de seguros para veículos, analisando a importância, as vantagens e desvantagens da instalação de um rastreador veicular que utiliza o sinal GPS para o seu funcionamento.

O presente trabalho traz uma revisão de literatura minuciosa que mostra que há muito tempo o homem já notava que era necessária a sua noção de posição e localização na atmosfera terrestre. Para desenvolver o Sistema GPS combinaram recursos tecnológicos para desenvolver um sistema de navegação de alta precisão baseado em satélites artificiais que estão na órbita terrestre.

O Sistema GPS tem o seu alcance como sua principal vantagem, pois o alcance é ilimitado em toda a atmosfera do planeta, estar em funcionamento 24 horas por dia, diversas áreas e funcionalidades. E tem como desvantagens: as dificuldades de funcionamento bob túneis, zonas muito arborizadas e edificadas, necessita da visibilidade de no mínimo 3 satélites, as interferências nos sinais desde a emissão pelos satélites até a recepção pelos receptores.

Com as suas diferentes finalidades o Rastreador é um aparelho instalado no veículo

Nucleus, v.8, n.2, out.2011 
que utiliza o sinal GPS para o seu funcionamento com a finalidade de monitorar, rastrear, bloquear e localizar o veículo á distância no caso de furto ou roubo do veículo. E o navegador GPS tem como finalidade, o auxilio á condutores de veículos ou até mesmo aos pedestres na sua localização e indicação, com planos de rota, percorrendo melhores caminhos ou caminho mais curto.

No Brasil até o ano de 2006 os navegadores eram proibidos de serem utilizados em veículos, pois uma resolução no CONTRAN proibia o uso de qualquer equipamento eletrônico, com o intuito de não utilizar aparelhos de DVD no veículo, o que acabou incluindo os aparelhos de navegação GPS, pois também geram imagens. A resolução tinha como finalidade proibir os aparelhos para não distrair os condutores do veículo. A partir do ano de 2007 o CONTRAN substituiu a resolução e liberou o uso de sistemas de navegação a fins de auxiliar o condutor na indicação de trajetos e condições da via, por intermédio de mapas, imagens e símbolos.

Durante a realização do trabalho, notou-se que o equipamento de monitoramento e rastreamento tem como segurança uma margem de $95 \%$ de confiabilidade, pois é esta a porcentagem de veículos que possuem o equipamento instalado que é recuperado em casos de furto e roubo. Pode-se observar ainda de acordo com a presente pesquisa que na visão das seguradoras torna-se viável o uso do sistema de rastreamento e monitoramento de veículos, pela facilidade e segurança na localização e recuperação dos veículos que vierem a ser furtados ou roubados.

\section{REFERÊNCIAS}

ARIMA, K. GPS: Agora que os preços caíram, chegou a hora de comprar o seu? Info Exame n 266, p.43, abr. 2008.

BELORIO, C. L. Descrição de um sistema de rastreamento veicular utilizando GPS. Trabalho de Conclusão de Curso (Graduação em Sistemas de Informação) - Uniminas, Uberlândia, 2005.

BERNARDI, J.V.E. \& LANDIM, P.M.B. Aplicação do Sistema de Posicionamento Global (GPS) na coleta de dados. DGA,IGCE, UNESP/Rio Claro. 2002. Disponível em <http://www.rc.unesp.br/igce/aplicada/textodi.html>. Acesso em 08/08/2010.

BRANCO, Á; PRESTES, Viviane. Empresas de tecnologia agregam valores. Mercado. InfoGPS. V.3, n.12, p.28-31; 48 - 53, 2010. 
BRANCO, Á; PRESTES, V. Entrega com hora marcada. LBS. InfoGPS. V.3, n.13, p32, 2010.

BRANCO, Á; PRESTES, V. Entrega com hora marcada. Software. InfoGPS. V.3, n.13, 2010.

CARDOSO, A. da S. Aplicação de rastreamento veicular GPS/GSM utilizando dispositivos móveis. 2007, Disponível em: 〈www.garcia.pro.br/>. Acesso em 07 jul.2010.

CONTRAN - Conselho Nacional de Trânsito, RESOLUÇAO No. 245 DE 27 DE JULHO DE 2007. Disponível em: <http://www.denatran.gov.br/download/Resolucoes/RESOLUCAO CONTRAN_245.pdf $>$. Acesso em: 27 out. 2010.

FRANCO, G. Sistemas de Segurança: : Novidades da obrigatoriedade de antifurto. Crash de Alta Velocidade: Padrão Internacional em estudo de segurança chega ao Brasil, Revista CESVI, v. 65, n. 12, p.12-13, Ago/Set de 2009. Disponível em: <http://www.cesvibrasil.com.br/files/pdf/publicacoes/125_rc_b3fbc5d8-c56c-4045-91a05340ccca3bc0.pdf >. Acesso em: 27 out. 2010.

GASPAROTO, L.; PAIM, M.; MENTA, E. Matemática na prática: GPS. Disponível em: <http://portaldoprofessor.mec.gov.br/fichaTecnicaAula.html?aula=1480>. Acesso em: 20 abr. 2010 .

GONÇALVES, R. P. et al. Sistema de Posicionamento Global - GPS. UFV Geocapacitar, Viçosa-MG, 09 jul. 2010. Disponível em:

<www.ufv.br/nugeo/pag/PROEXT/UFVGeocapacitar_GPS.doc>. Acesso em: 09 jul. 2010.

GORGULHO, M. Conceito de GPS. Disponível em:

<http://www.maregps.com.br/images/sistema_gps.htm>. Acesso em: 23 nov. 2009.

GUIMARÃES, A.; GRIVET, M. A. Radiolocalização de Terminais de Comunicações

Móveis. Disponível em: <http://revista.inatel.br/revista/docman/v.6.01-junho-

2003/radiolocalizacao-de-terminais-de-comunicacoes-movei/view.html > . Acesso em: 24 maio 2010 .

MACHADO, W. Introdução ao sistema de posicionamento global - GPS. Disponível em: <www.sdtp.org.br/introducaoaogps.pdf> Acesso em: 01 maio 2010.

MINAYO, M. C. de S. O desafio do conhecimento: pesquisa qualitativa em saúde. 7 ed. São Paulo: Hucitec; Rio de Janeiro: Abrasco, 2000.

MONICO, J.F.G., Posicionamento pelo NAVSTAR-GPS: descrição, fundamentos e aplicações. Presidente Prudente: UNESP, 2000.

MUNDOGEO. Notícias Imagem de Satélite e Sensoriamento Remoto. Polícia encontra carros roubados no ABC paulista graças a rastreamento via satélite. 1 out. 2004. Disponível em <http://www.mundogeo.com.br/noticias-diarias.php?id_noticia=3979>. Acesso em: 03 mar. 2010 .

PAZ, S. M; CUGNASCA, C. E. O sistema de posicionamento global GPS e suas aplicações. Disponível em: 〈http://www.lps.usp.br/lps/arquivos/conteudo/grad/dwnld/ApostilaGPS.pdf $>$. Acesso em: 17 abr. 2010. 
PRATES, G. Navstar GPS Sistema de Posicionamento Global. Escola Superior de Tecnologia da Universidade do Algarve. Abril de 2004. Disponível em:

<http://w3.ualg.pt/ gprates/navstar_gps.pdf > . Acesso em: 25 set. 2010.

RICHARDSON, R. J. Pesquisa Social: métodos e técnicas. São Paulo: Atlas, 1999

SISTEMA de Posicionamento Global (GPS). Disponível em:

<www.epamig.br/geosolos/MN_GEO/GPS.PDF>. Acesso em: 09 jul. 2010. 